\title{
Tree thinning as an option to increase herbaceous yield of an encroached semi-arid savanna in South Africa
}

\section{Gert N Smit*}

Address: Department of Animal, Wildlife and Grassland Sciences, University of the Free State, P.O. Box 339, Bloemfontein 9300, Republic of South Africa

Email: Gert N Smit* - smitgn.sci@mail.uovs.ac.za

* Corresponding author

Published: 28 May 2005

BMC Ecology 2005, 5:4 doi:10.1 186/1472-6785-5-4

This article is available from: http://www.biomedcentral.com/l472-6785/5/4

This is an Open Access article distributed under the terms of the Creative Commons Attribution License (http://creativecommons.org/licenses/by/2.0), which permits unrestricted use, distribution, and reproduction in any medium, provided the original work is properly cited.

\begin{abstract}
Background: The investigation was conducted in a savanna area covered by what was considered an undesirably dense stand of Colophospermum mopane trees, mainly because such a dense stand of trees often results in the suppression of herbaceous plants. The objectives of this study were to determine the influence of intensity of tree thinning on the dry matter yield of herbaceous plants (notably grasses) and to investigate differences in herbaceous species composition between defined subhabitats (under tree canopies, between tree canopies and where trees have been removed). Seven plots $(65 \times 180 \mathrm{~m})$ were subjected to different intensities of tree thinning, ranging from a totally cleared plot ( $0 \%$ ) to plots thinned to the equivalent of $10 \%, 20 \%, 35 \%, 50 \%$ and $75 \%$ of the leaf biomass of a control plot ( $100 \%)$ with a tree density of $27 \mathrm{II}$ plants ha ${ }^{-1}$. The establishment of herbaceous plants (grasses and forbs) in response to reduced competition from the woody plants was measured during three full growing seasons following the thinning treatments.
\end{abstract}

Results: The grass component reacted positively to the tree thinning in terms of total dry matter (DM) yield, but forbs were negatively influenced. Rainfall interacted with tree density and the differences between grass DM yields in thinned plots during years of below average rainfall were substantially higher than those of the control. At high tree densities, yields differed little between seasons of varying rainfall. The relation between grass DM yield and tree biomass was curvilinear, best described by the exponential regression equation. Subhabitat differentiation by $C$. mopane trees did provide some qualitative benefits, with certain desirable grass species showing a preference for the subhabitat under tree canopies.

Conclusion: While it can be concluded from this study that high tree densities suppress herbaceous production, the decision to clear/thin the $C$. mopane trees should include additional considerations. Thinning of $C$. mopane with the exclusive objective of increasing productivity of the grass layer would thus invariably involve a compromise situation where some trees should be left for the sake of the qualitative benefits on the herbaceous layer, soil enrichment, provision of browse and stability of the ecosystem.

\section{Background}

In addition to browsing by domestic stock and game the direct uses of woody plants in southern African savannas include their use as firewood, rough construction timber, 
the production of charcoal and woodcarvings. In areas where trees are used for timber, harvest rates commonly exceed replacement rates. In other areas where woody plants are not subjected to harvesting and where cattle and game ranching are practised exclusively, an increase in woody plant abundance is common. This increase in woody plant abundance is commonly referred to as "bush encroachment" and involves the invasion of grasslands and the thickening of savanna [1].

The reasons for bush encroachment in savanna are diverse and complex. In most situations the determinants of savanna ecosystems were modified by man, either directly or indirectly. These determinants may either be primary (such as climate and soil) or secondary (such as fire and the impact of herbivores) [2-4]. The latter are of particular interest since, although they act within the constraints imposed by the primary determinants, they can often be directly modified by management. Examples are the exclusion of occasional hot, top killing brush fires, the replacement of most of the indigenous browsers and grazers by domestic (largely grazing) livestock often at extremely high stocking rates, the restriction of movement of herbivores by the erection of fences, long-term overgrazing of the herbaceous layer, notably during wet seasons, and the provision of artificial watering points $[5,6]$.

In extensively managed semi-arid savannas, the productivity of herbaceous plants, notably the grasses, is of primary importance. The Colophospermum mopane Kirk ex J. Léonard (Kirk ex Benth) dominated savanna of South Africa, like most of the southern African savanna ecosystems, is water-limited and an increase in woody plant abundance invariably results in the suppression of herbaceous plants (e.g. [7-11]). Due to this suppression effect, the grazing capacity of large areas of the South African $C$. mopane savanna is reported to have declined due to bush encroachment, often to such an extent that many previously economic livestock properties are now no longer economic [6]. This is often the major reason why tree thinning or even total clearing is considered. The most commonly used methods of bush control include both mechanical and chemical measures. Arboricides with tebuthiuron as active ingredient are often used, but due to the non-selective nature of this arboricide, trees are also mechanically cut and the stumps treated with arboricides of which picloram is the most common active ingredient. Due to a general lack of adequate herbaceous biomass for fuel, fire is not used in the area.

Results of tree thinning may, however, differ between vegetation types, and is complicated by the existence of not only negative tree-grass interactions, but also positive treegrass interactions. Due to the enrichment of soil under tree canopies [12-14], trees may have positive effects on grass growth. Positive interactions, such as the association of certain desirable grass species (notably Panicum maximum) with tree canopies, are a consequence of subhabitat differentiation (canopied and uncanopied subhabitats). Subhabitat differentiation is dependent on tree density, tree species and tree size $[14,15]$, while interactions with soil can also play a role.

The C. mopane savanna is an important savanna vegetation type of southern Africa (South Africa, Namibia, Botswana and Mozambique) and the total area in southern Africa under C. mopane vegetation types is estimated at $555000 \mathrm{~km}^{2}$ [16]. The C. mopane trees have extensive root systems [17] and their selective removal has a profound effect on the soil water regime [18]. This will invariably influence the tree-grass competitive interaction. An understanding of the exact nature and magnitude of such influences is an important prerequisite towards an understanding of the complex biological interactions that exist in these ecosystems.

As part of a comprehensive investigation into the effect of tree thinning on the South African C. mopane savanna, the objectives of this study were: (i) to determine the influence of intensity of tree thinning on the dry matter yield of herbaceous plants (notably grasses), (ii) to establish relations between tree density and herbaceous production, and (iii) to investigate differences in herbaceous species composition between defined subhabitats (under tree canopies, between tree canopies and where trees have been removed).

\section{Study area}

The study was conducted in the Limpopo Province of South Africa on a site located at $29^{\circ} 12^{\prime} \mathrm{E}, 22^{\circ} 19^{\prime} \mathrm{S}, 560 \mathrm{~m}$ above sea level. The savanna vegetation is locally described by Acocks [19] as "Mopani veld" and by Low \& Rebelo [20] as "Mopane Bushveld". Louw [21] made a further division of seven plant communities within the South African Mopane Bushveld, and the study area was located in, what he named the Colophospermum-Boscia community. This community covers about 60000 ha of the Mopane Bushveld. Louw [21] described this community as a virtually pure stand of Colophospermum mopane (synonym: Hardwickia mopane), interposed with a few individuals of Boscia foetida subsp. rehmanniana and Salvadora australis (synonym: S. angustifolia var. australis). Within the study area the most important grass species are Enneapogon cenchroides, Aristida adscensionis, Brachiaria deflexa, Cenchrus ciliaris and Digitaria eriantha.

The study area, before tree thinning, was characterized by the virtual absence of herbaceous plants, accompanied by severe soil degradation in the form of surface erosion and crust formations. Crust formations are known to reduce 
Table I: Percentages of the total surface area covered by the various habitats and subhabitats in each of the experimental plots.

\begin{tabular}{|c|c|c|}
\hline Subhabitat & Experimental plot & Area (\%) \\
\hline Between trees & $0 \%$ & 87.10 \\
\hline , & $10 \%$ & 86.58 \\
\hline , & $20 \%$ & 83.99 \\
\hline$"$ & $35 \%$ & 86.65 \\
\hline$"$ & $50 \%$ & 87.46 \\
\hline , & $75 \%$ & 85.92 \\
\hline$"$ & $100 \%$ & 82.92 \\
\hline Under trees & $0 \%$ & 0.00 \\
\hline , & $10 \%$ & 2.85 \\
\hline$"$ & $20 \%$ & 5.57 \\
\hline$"$ & $35 \%$ & 5.80 \\
\hline , & $50 \%$ & 8.82 \\
\hline$"$ & $75 \%$ & 10.85 \\
\hline$"$ & $100 \%$ & 17.08 \\
\hline Where trees & $0 \%$ & 12.90 \\
\hline were removed & $10 \%$ & 10.57 \\
\hline , & $20 \%$ & 10.44 \\
\hline$”$ & $35 \%$ & 7.55 \\
\hline$"$ & $50 \%$ & 3.72 \\
\hline , & $75 \%$ & 3.23 \\
\hline$"$ & $100 \%$ & 0.00 \\
\hline
\end{tabular}

infiltration and cause substantial losses due to rainfall runoff (e.g. [22-25]). The site was previously used as grazing for cattle, but due to a lack of adequate grazing, the cattle was removed from the area for a period of at least five years. Since then the area has mainly been grazed and browsed by an unknown number of free ranging game species.

The rainy season usually extends from October to March inclusively, but rainfall is irregularly distributed and unpredictable. Mean long-term seasonal rainfall (JulyJune) for the period 1966/67 to 1990/91 was $376 \mathrm{~mm}$ (SE \pm 27.6 , range: $140-620 \mathrm{~mm}$ ). The probability of rain falling during January is greater than for other months. The area is largely frost-free and is well known for its high summer temperatures and moderate to warm winter temperatures.

The underlying rock type is mainly sandstone [21] and the soil is predominantly sandy ( $80 \%$ sand, $8 \%$ silt, $12 \%$ clay). A detailed description of the soil is given by Smit \& Rethman [18].

\section{Results}

\section{Areas of subhabitats}

Three subhabitats were distinguished: between tree canopies (uncanopied - UCA), under tree canopies (canopied
Table 2: The number of EvapotranspirationTree Equivalents (ETTE) ha-1 within the various tree thinning plots and seasons.

\begin{tabular}{|c|c|c|}
\hline Season & Exp. plot & ETTE ha-1 \\
\hline \multirow[t]{6}{*}{ After thinning } & 10 & 605.5 \\
\hline & 20 & | 406.1 \\
\hline & 35 & I 717.4 \\
\hline & 50 & 3176.2 \\
\hline & 75 & 3376.7 \\
\hline & 100 & 5509.9 \\
\hline \multirow[t]{6}{*}{ Season I } & 10 & 707.5 \\
\hline & 20 & I 669.5 \\
\hline & 35 & 2008.0 \\
\hline & 50 & 3487.6 \\
\hline & 75 & 3602.9 \\
\hline & 100 & 5900.8 \\
\hline \multirow[t]{6}{*}{ Season 2} & 10 & 809.9 \\
\hline & 20 & I 885.5 \\
\hline & 35 & $2 \mid 36.1$ \\
\hline & 50 & 3503.3 \\
\hline & 75 & 3769.3 \\
\hline & 100 & 5962.3 \\
\hline \multirow[t]{6}{*}{ Season 3} & 10 & 998.4 \\
\hline & 20 & 2171.8 \\
\hline & 35 & 2540.8 \\
\hline & 50 & 3870.8 \\
\hline & 75 & 4197.2 \\
\hline & 100 & 6733.0 \\
\hline
\end{tabular}

- CA) and where trees have been removed (removed canopy - RCA). The areas covered by the various subhabitats are presented in Table 1 . The subhabitat between trees (uncanopied - UCA) predominates, also with small variation between treatments (mean of $85.8 \%$ ). Through tree thinning the subhabitat under trees canopies (canopied CA) decreased over the gradient of decreasing tree density, up to the point of no representation in the $0 \%$ plot. In contrast, the subhabitat where trees were removed (removed canopy - RCA), increased over this gradient, not being represented in the control plot (100\% plot).

\section{Leaf volume of the woody layer}

The estimated number of Evapotranspiration Tree Equivalents (ETTE) $\mathrm{ha}^{-1}$ of the C. mopane trees over the trial period is presented in Table 2. Detailed results and a discussion of the woody layer are reported elsewhere [2628].

\section{Dry matter yield of the herbaceous layer}

The total seasonal DM yield of grasses (subhabitats combined) is presented in Figure 1 and the total seasonal DM yield of grasses within the various subhabitats is presented 


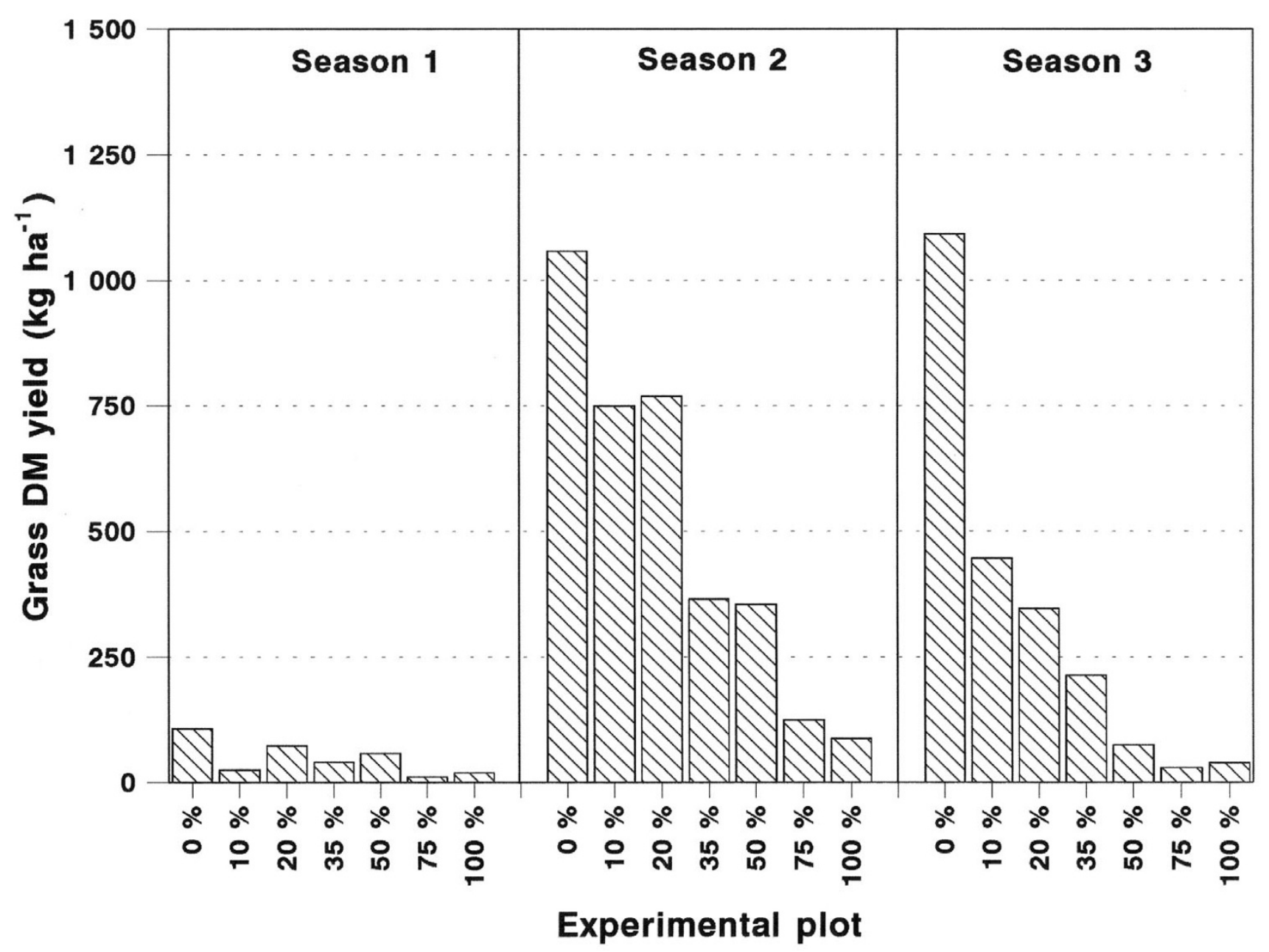

Figure I

Total seasonal DM yields of grasses as measured in die various tree thinning treatment plots during the three seasons following the tree thinning (the DM yields of the uncanopied, canopied and removed canopy subhabitats were combined).

in Figure 2. The grass DM yields were generally low during the first, low rainfall season season 1). In the following seasons the yields were substantially higher, with marked differences between treatments. Comparison of the grass DM yields between subhabitats, revealed differences. The yields between tree canopies (UCA) (Figure 2a) were initially of the same order as under tree canopies (CA) (Figure $2 \mathrm{~b}$ ), with the yields where trees have been removed (RCA) the highest (Figure 2c). While the seasonal grass yield patterns largely followed the rainfall pattern (Figure 3 ), the yields of the UCA subhabitat in the totally cleared plot ( $0 \%$ plot) continued to improve during the third season, which received less than half the rainfall of the previous season (season 2).
The fitting of polynomials to data of season 1 was unsuccessful, mainly due to the low rainfall and subsequent poor response of the grass layer. Polynomials were subsequently only fitted to the data for seasons 2 and 3 (Table 3 ). The testing of paired combinations (contrasts) [29] of these selected polynomials for significant differences on the $\mathrm{x}$-axis (ETTE ha-1) showed that total grass DM yields did not differ significantly $(P>0.05)$ between the UCA and CA-subhabitats, during both seasons 2 and 3 . In contrast, during season 2, up to 3927 ETTE ha-1, grass DM yields differed significantly $(\mathrm{P}<0.05)$ between the UCA and the RCA-subhabitats, with the yields being higher in the RCA-subhabitat. These differences changed during season 3 , with yields not differing significantly $(P>0.05)$ between the latter subhabitats over the complete ETTE gradient. The test of the contrast CA versus RCA showed 


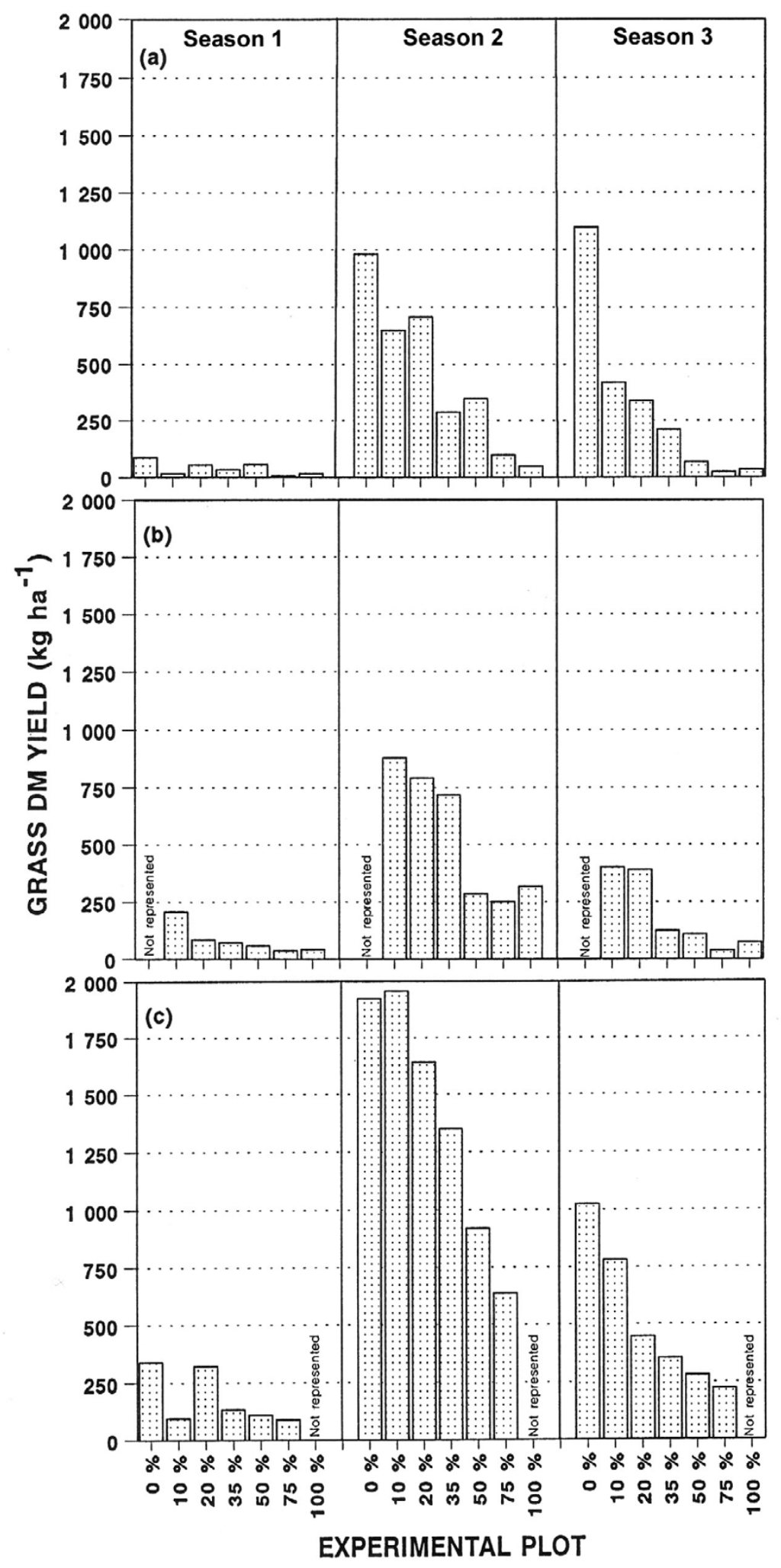

Figure 2

Total seasonal DM yields of grasses within the defined subhabitats during the three seasons following the tree thinning: (a) between tree canopies (uncanopied), (b) under trees (canopied), and (c) where trees have been removed (removed canopy). 


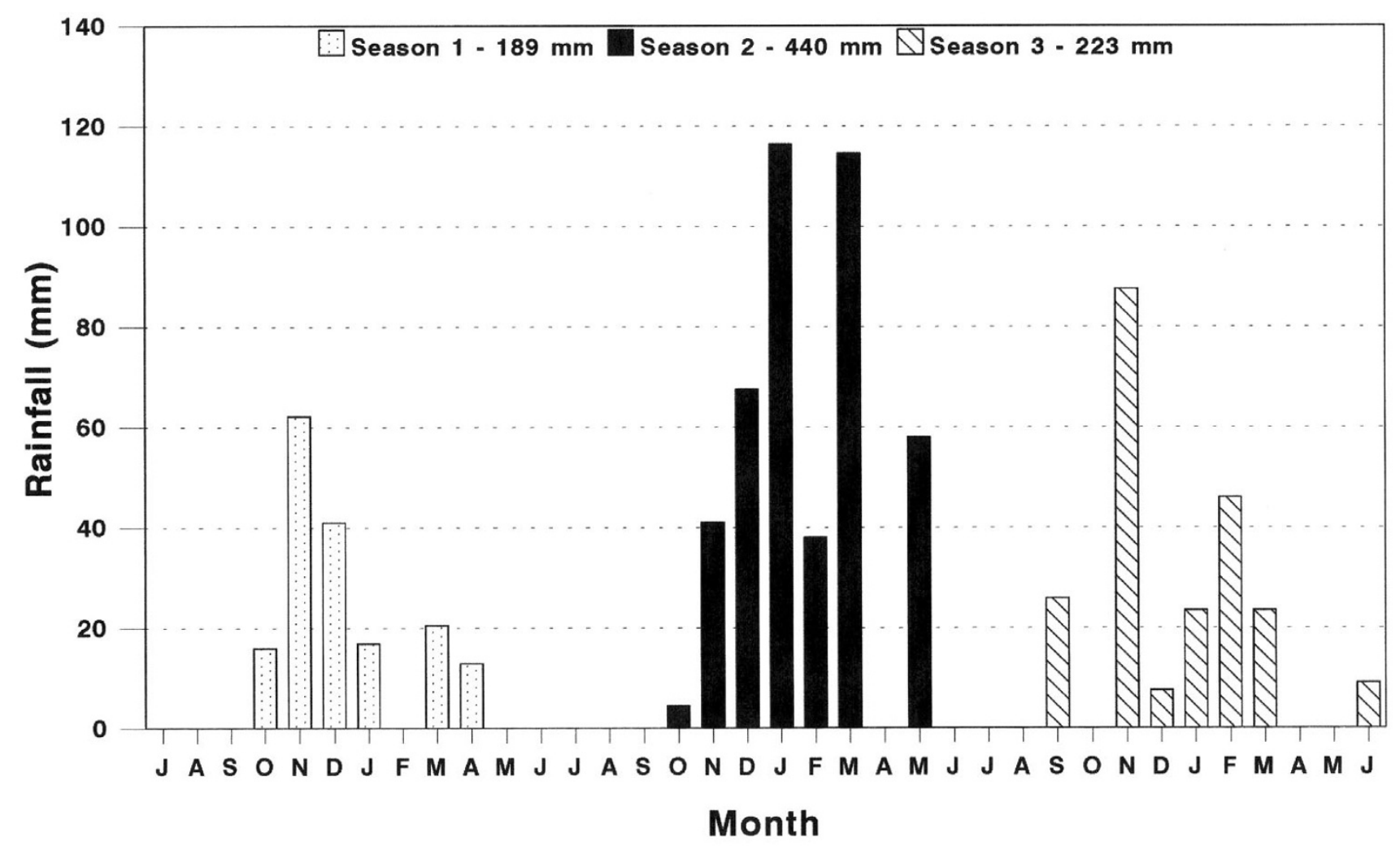

Figure 3

Monthly rainfall recorded at the Colophospermum mopane experimental site during the three seasons (July-June) of the trial period.

Table 3: Polynomials with the best fit $(y=$ total grass DM yield, $x=$ ETTE ha-1)

\begin{tabular}{cclr}
\hline Subhabitat & Season after thinning & Polynomial & $r^{2}$ \\
\hline UCA & 2 & quadratic: $y=948.0-0.278+0.000021 x^{2}$ & 0.78 \\
UCA & 3 & quadratic: $y=980.0-0.3985+0.000039 x^{2}$ & 0.021 \\
CA & 2 & cubic: $686.3-0.4284 x+0.000254 x^{2}+0.29 \mathrm{E}-7 x^{3}$ & 0.005 \\
CA & 3 & quadratic: $630.0-0.2132 x+0.000019 x^{2}$ & 0.003 \\
RCA & 2 & quadratic: I $968.0-0.066 x-0.000073 x^{2}$ & 0.99 \\
RCA & 3 & quadratic: I $047.3-0.3558 x+0.000038 x^{2}$ & 0.64 \\
\hline
\end{tabular}

that during season 2 yields differed significantly $(\mathrm{P}<0.05)$ up to a density of 3817 ETTE ha $^{-1}(0 \%, 10 \%, 20 \%, 35 \%$ and $50 \%$ plots), with the yields being higher in the RCAsubhabitat. Similar to the UCA/RCA contrast, yields did not differ significantly $(\mathrm{P}>0.05)$ between these subhabitats during season 3 .

\section{Relationship between tree leaf biomass and herbaceous dry matter yield}

The relationship between tree leaf biomass, expressed as Evapotranspiration Tree Equivalents (ETTE) $\mathrm{ha}^{-1}$ and total grass DM yield (all subhabitats combined) of each treatment plot was established (Figure 4). The relationships between ETTE ha-1 and grass DM yield within each of the defined subhabitats are presented in Table 4 . The relations 
between ETTE ha-1 and the DM yield of forbs within these subhabitats are presented in Table 5 .

From Figure 4a there is a negative trend between ETTE ha${ }^{1}$ and total grass DM yield of the combined subhabitats. However, following thinning, this negative trend changed significantly with each season. It changed from a non-significant $(P>0.05)$ linear relation during the first (dry) season (Figure $4 \mathrm{a})$ to a significant curvilinear $(\mathrm{P}<0.05)$ relationship during the second and third seasons (Figure $4 \mathrm{~b} \& 4 \mathrm{c})$. The best fit to these curvilinear relations was achieved by the exponential regression equation. The gradient of the curve was steeper in the relationship established for season 3 (Figure 4c), indicating an increasing difference between grass DM yields of the totally cleared plot $(0 \%)$ and the rest of the treatments.

Examination of the grass DM yields within the respective subhabitats revealed trends similar to that already presented for the combined subhabitats. Significant $(\mathrm{P}<$ $0.05)$ negative relationships between grass yield and ETTE ha $^{-1}$ are particularly eminent after the second and third seasons within the UCA and RCA-subhabitats. This negative relationship was less strongly defined in the CA-subhabitat (Table 4).

The reaction of forbs to the thinning of $C$. mopane differed markedly from that of the grasses (Table 5). With few exceptions, the yields of forbs were mostly positively associated with ETTE ha $^{-1}$, though the relations were mostly statistically non-significant $(P>0.05)$. This implies that they were predominantly negatively affected by tree thinning. Some variation between subhabitats was also found, but a consistent pattern was lacking.

\section{Grass species differences between subhabitats}

The mean percentage contributions (on a dry mass basis) of the most abundant grass species to the total grass DM yield within the defined subhabitats are presented in Table 6. By non-statistical inspection it appeared as if Tragus berteronianus, Aristida species and Oropetium capensis were mostly more abundant within the UCA-subhabitat. Preferences for the CA-subhabitat were shown by Cenchrus ciliaris, Digitaria eriantha and Panicum maximum. Those with no apparent preferences were Brachiaria deflexa and Enneapogon cenchroides, being abundant in all subhabitats. No conclusion can be drawn for Urochloa mosambicensis, Bothriochloa radicans and Sporobolus ioclados due to a low representation. Preferences for the RCA-subhabitat are likely to be transient in view of the expected short-term advantage that the RCA-subhabitat offers.

\section{Discussion}

The botanical composition and productivity of any mature stand of vegetation is largely determined by com- petition [30]. The roots of woody plants are fundamental in their competitive interactions with herbaceous plants and other woody plants. Roots determine the spatial distribution of water and nutrient uptake and can cause an increase or a decrease in resource availability [31]. This aspect was clearly illustrated within the study area [28] where it was demonstrated that the total root biomass of C. mopane ranged from $9760 \mathrm{~kg} \mathrm{ha}^{-1}$ to $29790 \mathrm{~kg} \mathrm{ha}^{-1}$ (mean: $17354 \mathrm{~kg} \mathrm{ha}^{-1}$ ). Of these a mean of $19 \%$ was in the $0-1.0 \mathrm{~mm}$ diameter class, and $20.3 \%, 16.2 \%$ and $44.5 \%$ in the $>1.0-5.0 \mathrm{~mm},>5.0-10.0 \mathrm{~mm}$ and $>10 \mathrm{~mm}$ diameter classes respectively. A mean of $66.1 \%$ of all fine roots $(<5.0 \mathrm{~mm})$ was found within the first $400 \mathrm{~mm}$ of the soil [28].

A subsequent study [18] presented evidence that the roots of the C. mopane trees are able to utilise soil water at a matric potential lower than that of grasses $(\psi<-1500 \mathrm{kPa})$. This feature, combined with high rainwater runoff losses due to a lack of a herbaceous cover, resulted in a dramatic reduction in the amount of plant available water with an increase in tree density. This enables the C. mopane trees to compete successfully with herbaceous plants and to prevent their establishment at high tree densities.

In view of this knowledge the observed increase in grass DM yield after the thinning of the C. mopane trees was expected. Indeed competitive interactions between the woody and herbaceous components of savannas, involving mainly available soil water as the primary determinant of production, have been reported world-wide (Australia: [32-35]; North America: [36-40]; southern and east Africa: $[8,9,11,12,14])$. While the existence of negative competition interactions between woody and herbaceous plants are thus nothing new, the results of this study is of particular significance, which relates to the magnitude and scale of the competition interaction.

The suppressive effect of the C. mopane trees on the grass DM yield at high tree densities is severe and for this reason the thinning of the C. mopane trees resulted in significant and desirable increases in grass DM yields (Figures 1 and 2 ). It is also worthy to note that during a wet year, like the second season, the grass DM yield differed substantially (1211\%) between the extreme ends of the competition gradient ( $0 \%$ versus $100 \%$ plots), but the difference enlarged even further $(2778 \%)$ during a dry season (season 3 ). This substantiates the general assumption that the consequences of bush encroachment is at its worst during dry periods [9].

The gradual establishment of the strong negative relation between grass DM yield and ETTE ha-1 is clearly illustrated in Figure 4. As bare soil became colonised by grasses in the plots with a low tree density, runoff of rainfall was increas- 


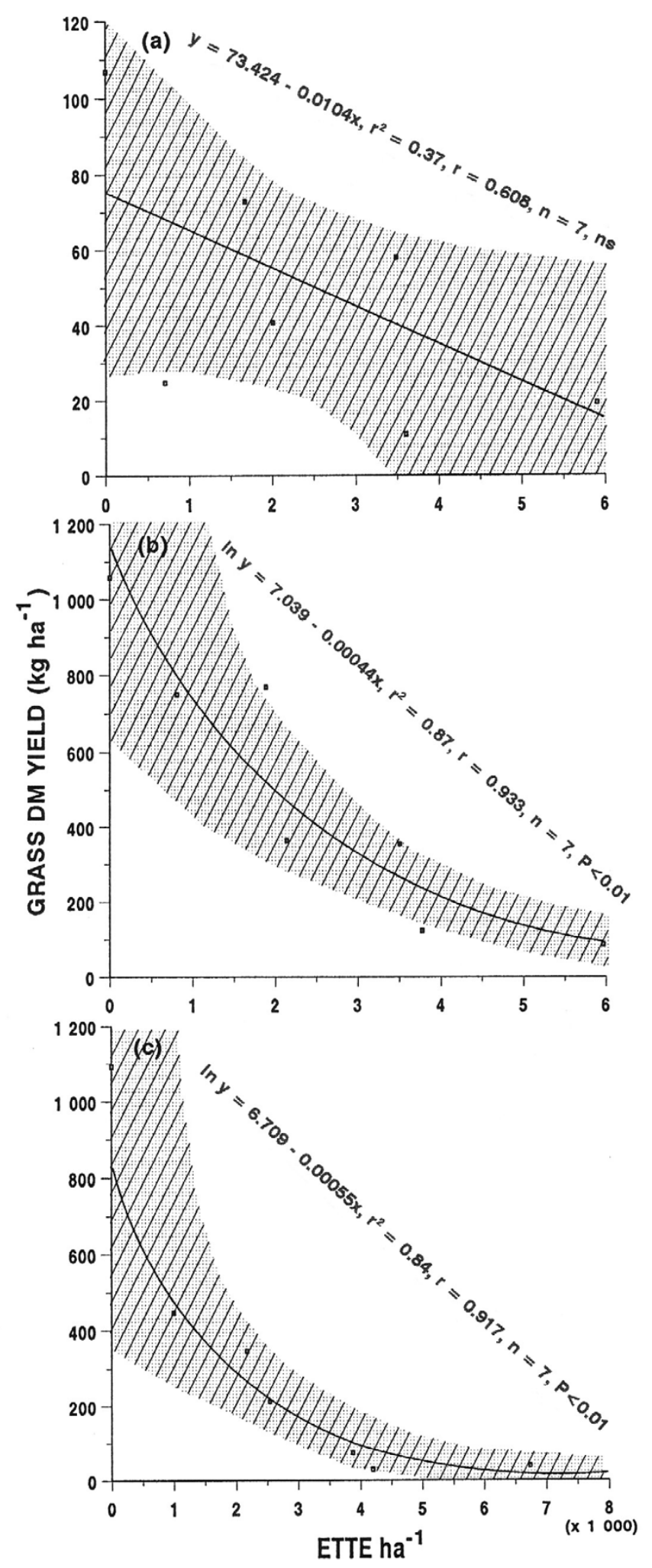

Figure 4

Results of the regression analyses of the relations between the grass DM yield (subhabitats combined) and the Evapotranspiration Tree Equivalents (ETTE) ha-1 (shaded area shows the $95 \%$ confidence limits): (a) season I, (b) season 2, and (c) season 3. 
Table 4: Results of the regression analyses of the relations between the DM yields of grasses within the defined subhabitats (dependent variable) and Evapotranspiration Tree Equivalents (ETTE) ha-1 (independent variable).

\begin{tabular}{|c|c|c|c|c|c|c|}
\hline Subhabitat & Season & Regression equation & $r^{2}$ & $r$ & $\mathrm{n}$ & $P$ \\
\hline \multirow[t]{3}{*}{ Between trees (UCA) } & 1 & $y=57.188-0.00765 x$ & 0.282 & -0.532 & 7 & $0.220 \mathrm{~ns}$ \\
\hline & 2 & $\ln y=7.017-0.000510 x$ & 0.861 & -0.928 & 7 & $0.003 * *$ \\
\hline & 3 & $\ln y=6.708-0.000579 x$ & 0.828 & -0.910 & 7 & $0.004 * *$ \\
\hline \multirow[t]{3}{*}{ Under trees $(C A)$} & 1 & $\ln y=5.052-0.000274 x$ & 0.679 & -0.824 & 7 & $0.044 *$ \\
\hline & 2 & $\ln y=6.936-0.000257 x$ & 0.662 & -0.814 & 7 & $0.049 *$ \\
\hline & 3 & $\ln y=6.099-0.000349 x$ & 0.567 & -0.753 & 7 & $0.084 \mathrm{~ns}$ \\
\hline \multirow[t]{3}{*}{ Trees removed (RCA) } & 1 & $y=274.648-0.0479 x$ & 0.358 & -0.599 & 7 & $0.209 \mathrm{~ns}$ \\
\hline & 2 & $\ln y=7.745-0.000284 x$ & 0.868 & -0.932 & 7 & $0.007 * *$ \\
\hline & 3 & $\ln y=6.936-0.000466 x$ & 0.980 & -0.990 & 7 & $0.002 * *$ \\
\hline
\end{tabular}

Table 5: Results of the regression analyses of the relations between the DM yields of forbs within the defined subhabitats (dependent variable) and Evapotranspiration Tree Equivalents (ETTE) ha-1 (independent variable).

\begin{tabular}{|c|c|c|c|c|c|c|}
\hline Subhabitat & Season & Regression equation & $r^{2}$ & $r$ & $\mathrm{n}$ & $P$ \\
\hline \multirow[t]{3}{*}{ Between trees (UCA) } & 1 & $\ln y=2.756+0.000214 x$ & 0.137 & 0.370 & 7 & $0.414 \mathrm{~ns}$ \\
\hline & 2 & $y=43.396+0.01467 x$ & 0.272 & 0.521 & 7 & $0.230 \mathrm{~ns}$ \\
\hline & 3 & $\ln y=3.911+0.000156 x$ & 0.126 & 0.355 & 7 & $0.434 \mathrm{~ns}$ \\
\hline \multirow[t]{3}{*}{ Under trees $(\mathrm{CA})$} & 1 & $y=-65.59+0.12309 x$ & 0.675 & 0.822 & 7 & $0.045 *$ \\
\hline & 2 & $y=90.378+0.05286 x$ & 0.813 & 0.902 & 7 & $0.014 *$ \\
\hline & 3 & $y=139.76+0.04719 x$ & 0.416 & 0.645 & 7 & $0.167 \mathrm{~ns}$ \\
\hline \multirow[t]{3}{*}{ Trees removed (RCA) } & 1 & $y=21.291+0.00130 x$ & 0.021 & 0.146 & 7 & 0.783 ns \\
\hline & 2 & $y=72.022-0.01599 x$ & 0.537 & -0.733 & 7 & $0.098 \mathrm{~ns}$ \\
\hline & 3 & $\ln y=0.888+0.000824 x$ & 0.611 & 0.781 & 7 & $0.066 \mathrm{~ns}$ \\
\hline
\end{tabular}

ingly reduced, increasing the amount of soil water available to the establishing grasses [18]. This resulted in increased differences in grass DM yield between plots at the extreme ends of the ETTE gradient. This phenomenon is clearly illustrated in Figure 1 where the grass DM yield in all the plots followed the pattern of seasonal rainfall, except in the totally cleared plot $(0 \%)$ which continued to improve during the third season, while receiving less than half of the rainfall of the previous wet season (second season). At the other end of the gradient, grass DM yields differed little between years of below and above average rainfall (75\% and $100 \%$ plots). This is typical of a human induced drought situation and not a climatic drought.

The negative curvilinear relationship between tree density and grass DM yield evident on the experimental site as a whole, as well as within the individual subhabitats, corresponds to those described for some other savanna vegetation types (e.g. [7-9], [32-34]). This relation implies that the highest grass DM yield is obtained where all the $C$. mopane trees are removed. Since grass yields under tree canopies were not significantly higher than between tree canopies, and the high yields where trees were removed are likely only temporary, it would appear that no advantageous tree-grass interactions, evident in several other savanna vegetation types (e.g. [12-15], [41-44]) occur in this vegetation type. This, at least, applies to the total grass DM yield and not to possible differences in grass species composistion.

While subhabitat differentiation did not present any advantage in respect of total grass DM yield, differences with regard to grass species composition between subhabitats were, however, present (Table 6). On evaluating these species differences, it is clear that the CA-subhabitat is important to the presence of desirable perennial grass species like Cenchrus ciliaris, Digitaria eriantha and Panicum maximum. These are also the species with the highest 
Table 6: Mean percentage contribution (on a dry mass basis) of the most abundant grass species to the total grass DM yield within the defined subhabitats.

\begin{tabular}{|c|c|c|c|c|}
\hline \multirow[t]{2}{*}{ Grass species } & \multirow[t]{2}{*}{ Exp. plot } & \multicolumn{3}{|c|}{ Mean \% contribution (standard error) } \\
\hline & & Between trees (UCA) & Under trees $(\mathrm{CA})$ & Trees removed (RCA) \\
\hline Tragus berteronianus & $0 \%$ & $14.70(7.30)$ & - & $7.23(4.55)$ \\
\hline , & $10 \%$ & $8.30(4.33)$ & $4.30(3.09)$ & $5.73(5.29)$ \\
\hline$"$ & $20 \%$ & $19.03(12.97)$ & $6.50(3.26)$ & $13.40(6.95)$ \\
\hline , & $35 \%$ & $28.57(14.32)$ & $9.03(4.12)$ & $7.03(6.54)$ \\
\hline$"$ & $50 \%$ & $14.23(7.23)$ & $3.57(2.5 \mathrm{I})$ & $5.13(4.84)$ \\
\hline$"$ & $75 \%$ & $11.00(6.32)$ & $3.60(2.75)$ & $5.90(5.55)$ \\
\hline$"$ & $100 \%$ & $10.87(8.76)$ & $2.10(2.10)$ & - \\
\hline Aristida species & $0 \%$ & $56.80(2.59)$ & - & $10.53(1.43)$ \\
\hline , & $10 \%$ & $38.23(2.69)$ & $12.93(7.35)$ & $6.23(1.53)$ \\
\hline$"$ & $20 \%$ & $31.17(4.93)$ & $14.33(5.80)$ & $6.90(3.58)$ \\
\hline$"$ & $35 \%$ & $8.97(2.41)$ & $5.23(3.25)$ & $8.27(3.93)$ \\
\hline 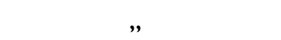 & $50 \%$ & $12.00(6.89)$ & $6.57(3.31)$ & $5.47(2.39)$ \\
\hline$"$ & $75 \%$ & $23.37(20.02)$ & $4.53(2.58)$ & $9.37(7.00)$ \\
\hline$”$ & $100 \%$ & $23.73(7.05)$ & $0.13(0.13)$ & 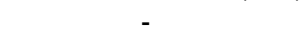 \\
\hline Oropetium capensis & $0 \%$ & $1.93(1.41)$ & - & $0.13(0.13)$ \\
\hline , & $10 \%$ & 3.47 (1.09) & $0.70(0.60)$ & $0.27(0.22)$ \\
\hline$"$ & $20 \%$ & $6.33(4.16)$ & $2.17(1.31)$ & $0.03(0.03)$ \\
\hline$"$ & $35 \%$ & 9.37 (4.27) & 3.67 (1.95) & $0.17(0.17)$ \\
\hline$"$ & $50 \%$ & 14.17 (3.68) & 3.90 (I.57) & $0.10(0.10)$ \\
\hline$"$ & $75 \%$ & $35.60(15.69)$ & $5.97(0.85)$ & $0.00(0.00)$ \\
\hline$"$ & $100 \%$ & $21.83(2.28)$ & $4.93(2.17)$ & - \\
\hline Cenchrus ciliaris & $0 \%$ & 1.67 (1.67) & - & $2.10(1.24)$ \\
\hline , & $10 \%$ & $0.00(0.00)$ & $0.00(0.00)$ & $2.97(1.49)$ \\
\hline$"$ & $20 \%$ & $0.00(0.00)$ & 7.63 (3.7I) & $1.20(1.20)$ \\
\hline$"$ & $35 \%$ & $0.00(0.00)$ & $0.00(0.00)$ & $0.00(0.00)$ \\
\hline$"$ & $50 \%$ & $0.00(0.00)$ & $4.33(4.33)$ & $0.00(0.00)$ \\
\hline , & $75 \%$ & $0.00(0.00)$ & $10.77(9.21)$ & $0.50(0.50)$ \\
\hline$"$ & $100 \%$ & $0.00(0.00)$ & $19.63(11.67)$ & - \\
\hline Digitaria eriantha & $0 \%$ & $0.00(0.00)$ & - & $1.87(1.13)$ \\
\hline , & $10 \%$ & $1.20(1.20)$ & $6.00(3.8 I)$ & $2.00(0.91)$ \\
\hline$”$ & $20 \%$ & $0.00(0.00)$ & $6.50(1.50)$ & $8.17(3.13)$ \\
\hline$"$ & $35 \%$ & $0.00(0.00)$ & $2.10(2.10)$ & $2.80(0.90)$ \\
\hline$"$ & $50 \%$ & $0.00(0.00)$ & $17.60(10.49)$ & $8.80(4.28)$ \\
\hline$"$ & $75 \%$ & $0.00(0.00)$ & $10.10(3.26)$ & $9.93(8.52)$ \\
\hline$"$ & $100 \%$ & $2.37(2.37)$ & $40.10(15.54)$ & - \\
\hline Panicum maximum & $0 \%$ & $0.00(0.00)$ & - & $6.53(6.53)$ \\
\hline , & $10 \%$ & $0.00(0.00)$ & $12.60(12.60)$ & $0.00(0.00)$ \\
\hline$"$ & $20 \%$ & $0.00(0.00)$ & $0.00(0.00)$ & $0.00(0.00)$ \\
\hline$”$ & $35 \%$ & $0.00(0.00)$ & $7.43(7.43)$ & $2.60(2.60)$ \\
\hline$"$ & $50 \%$ & $0.00(0.00)$ & $0.00(0.00)$ & $0.00(0.00)$ \\
\hline 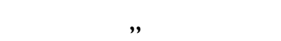 & $75 \%$ & $0.00(0.00)$ & $3.57(3.57)$ & $3.83(3.83)$ \\
\hline$"$ & $100 \%$ & $0.00(0.00)$ & $0.00(0.00)$ & - \\
\hline Brachiaraia deflexa & $0 \%$ & $4.93(3.79)$ & - & I5.40 (II.72) \\
\hline, & $10 \%$ & $6.40(3.13)$ & $21.33(11.18)$ & $18.77(15.40)$ \\
\hline$"$ & $20 \%$ & $1.17(0.69)$ & $15.67(10.05)$ & II.87 (7.89) \\
\hline ” & $35 \%$ & $12.10(6.14)$ & $26.57(13.32)$ & $30.40(19.93)$ \\
\hline$"$ & $50 \%$ & $25.77(12.91)$ & $36.60(20.58)$ & $35.77(15.44)$ \\
\hline$"$ & $75 \%$ & $21.57(12.27)$ & $41.00(21.95)$ & 30.23 (13.99) \\
\hline ” & $100 \%$ & $10.60(6.74)$ & $26.40(19.59)$ & - \\
\hline Enneapogon cenchroides & $0 \%$ & $16.57(8.67)$ & - & $47.10(13.78)$ \\
\hline
\end{tabular}


Table 6: Mean percentage contribution (on a dry mass basis) of the most abundant grass species to the total grass DM yield within the defined subhabitats. (Continued)

\begin{tabular}{|c|c|c|c|c|}
\hline$"$ & $10 \%$ & $36.63(2.47)$ & $38.83(13.97)$ & $5 \mathrm{I} .63(2 \mathrm{I} .4 \mathrm{I})$ \\
\hline , & $20 \%$ & $37.57(13.30)$ & $42.40(9.12)$ & $54.20(17.82)$ \\
\hline , & $35 \%$ & $12.03(6.03)$ & $29.20(17.05)$ & $39.53(16.10)$ \\
\hline$"$ & $50 \%$ & $26.03(12.07)$ & 18.77 (12.37) & $42.83(15.25)$ \\
\hline , & $75 \%$ & $6.23(3.83)$ & $20.57(12.13)$ & $36.30(5.18)$ \\
\hline$"$ & $100 \%$ & $0.60(0.60)$ & $6.30(5.33)$ & - \\
\hline Bothriochloa radicans & $0 \%$ & $0.00(0.00)$ & - & $0.00(0.00)$ \\
\hline , & $10 \%$ & $0.00(0.00)$ & $0.00(0.00)$ & $9.13(9.13)$ \\
\hline$"$ & $20 \%$ & $4.43(4.43)$ & $4.83(4.25)$ & $0.00(0.00)$ \\
\hline$"$ & $35 \%$ & $7.37(2.35)$ & $14.40(9.46)$ & $9.23(3.38)$ \\
\hline$"$ & $50 \%$ & $4.17(2.77)$ & $0.00(0.00)$ & $0.00(0.00)$ \\
\hline$"$ & $75 \%$ & $2.30(2.30)$ & $0.00(0.00)$ & $1.00(1.00)$ \\
\hline , & $100 \%$ & $19.97(10.38)$ & $0.50(0.50)$ & - \\
\hline Sporobolus ioclados & $0 \%$ & $0.00(0.00)$ & - & $6.63(6.63)$ \\
\hline " & $10 \%$ & $5.83(5.83)$ & $1.97(1.82)$ & $3.30(2.10)$ \\
\hline , & $20 \%$ & $0.00(0.00)$ & $0.00(0.00)$ & 1.67 (1.67) \\
\hline , & $35 \%$ & $0.00(0.00)$ & $0.00(0.00)$ & $0.00(0.00)$ \\
\hline 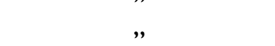 & $50 \%$ & $1.33(1.33)$ & $0.00(0.00)$ & $1.97(1.97)$ \\
\hline , & $75 \%$ & $0.00(0.00)$ & $0.00(0.00)$ & $0.00(0.00)$ \\
\hline$"$ & $100 \%$ & $0.00(0.00)$ & $0.00(0.00)$ & - \\
\hline Urochloa mosambicensis & $0 \%$ & $3.40(1.76)$ & - & $2.40(1.88)$ \\
\hline " & $10 \%$ & $0.00(0.00)$ & $0.00(0.00)$ & $0.00(0.00)$ \\
\hline$"$ & $20 \%$ & $0.00(0.00)$ & $0.00(0.00)$ & $2.60(2.60)$ \\
\hline , & $35 \%$ & $0.00(0.00)$ & $0.00(0.00)$ & $0.00(0.00)$ \\
\hline , & $50 \%$ & $2.30(2.30)$ & $0.00(0.00)$ & $0.00(0.00)$ \\
\hline , & $75 \%$ & $0.00(0.00)$ & $0.00(0.00)$ & $0.00(0.00)$ \\
\hline , & $100 \%$ & $0.00(0.00)$ & $0.00(0.00)$ & - \\
\hline
\end{tabular}

nutritional characteristics. Though these species did not constitute a large proportion of the grass species composition, they may play an important role in the total nutrition of grazing herbivores should they increase under improving management conditions.

A possible explanation for the negative reaction of forbs to tree thinning, lies in the seemingly inability of forbs to compete with establishing grasses. Thus, in those plots at the low end of the ETTE gradient, forbs were being replaced by strongly competitive grasses. The decrease of forbs can therefore be considered as a secondary consequence of the removal of $C$. mopane trees. However, it can be expected that the different forb species will react differently to competition from grasses, as well as to subhabitat changes. Thus, a proper understanding of the dynamics of forbs would necessitate an evaluation on a species basis.

The results of this study must be viewed in relation to different hypotheses of tree-grass dynamics, especially in semi-arid environments. This will invariably have an influence on the decision of the desirability to thin or clear the C. mopane trees for the purpose of increasing the herbaceous yield.

The terms "equilibrium" and "non-equilibrium" as used in rangelands, are points of strong debate among scientists. The central aspect of this debate is the definition of the degree to which climate or consumers (herbivores) influence vegetation. One view is that consumers reach densities that degrade environments from a previous condition of equilibrium and the other view is that the dynamics of pastoral systems are non-equilibrial and primarily dictated by variability in rainfall [45].

Higgins et al. [46] suggested a non-equilibrium mechanism of coexistence for savanna ecosystems. According to their model, grasses and trees coexist for a wide range of environmental conditions, and exhibit long periods of slow decline in adult tree numbers interspersed with relatively infrequent recruitment events. Recruitment is controlled by rainfall (which limits seedling establishment) and fire (which prevents recruitment into adult size classes). On the other hand, Illius and O'Connor [47] argued that the view that herbivory has little impact on cli- 
matically variable ecosystems is unjustified. They proposed an alternative model in which it is assumed that despite the apparent lack of an equilibrium, animal numbers are regulated in a density-dependent manner by the limited forage available in key resource areas which are utilized in the dry season. Their model asserts that strong equilibrial forces exist over a limited part of the system, with the animal population virtually uncoupled from resources elsewhere in the system.

While these arguments mainly relate to the causes and mechanisms according to which the woody plants increase (bush encroachment), the results of this study clearly showed that once the C. mopane has established, the suppression of the herbaceous layer was such that rainfall had very little effect on annual herbaceous yields in plots with high tree densities. Rainfall only played a significant role on herbaceous yields in plots where tree densities were reduced. Furthermore, the tree densities remained very stable at high tree densities with no indication, yet, of a natural process of restoration from its current encroached state.

\section{Conclusion}

From this study it can be concluded that the grass component of the herbaceous layer, in terms of total DM yield, reacted positively to the tree thinning treatments, but forbs were negatively influenced. It is also evident that rainfall played an important role by interacting with tree density in influencing grass DM yields. Comparatively, the grass DM yields in thinned plots were substantially higher than those of the control plot during years of below average rainfall, while at high tree densities yields differed little between seasons of varying rainfall.

At high tree densities the suppressive effect of the C. mopane trees approach complete suppression of the grass layer. The observed curvilinear relationship between grass DM yield and ETTE ha $^{-1}$, best described by the exponential regression equation, implies that the highest grass DM yields will be achieved when all the C. mopane trees are removed.

The question may then be asked if total tree clearing is the recommended option for land managers who have to deal with this problem in a practical manner. Based on some observed qualitative benefits of subhabitat differentiation by the C. mopane trees, with certain desirable grass species that showed a preference for the CA-subhabitat, the answer is not an unconditional yes. It is assumed that these desirable grass species would probably be lost with the complete removal of the C. mopane trees. From the literature it is also known that during practical tree thinning operations, re-encroachment is a common problem [28]. Through selective tree thinning, the development of a structured savanna with large trees is encouraged, and these large trees are able to suppress the establishment of new seedlings [5]. Total removal of all the C. mopane trees is therefore expected to be conducive to the rapid reencroachment of the cleared area. Thinning of $C$. mopane with the exclusive objective of increasing productivity of the grass layer would thus invariably involve a compromise situation where some trees should be left for the sake of the qualitative benefits on the herbaceous layer, soil enrichment, provision of browse and stability of the ecosystem.

While the benefits of tree thinning (not total clearing) in terms of increased herbaceous yield was demonstrated in this study, the issue of cost poses a substantial limitation on the practical implementation of bush control measures in the C. mopane savanna vegetation. An economical evaluation of different chemical and mechanical bush control measures was beyond the scope of this study, but hopefully this study will provide essential quantitative botanical data for a thorough economical evaluation.

\section{Methods \\ Trial layout}

The study area consisted of seven, 1.17 ha plots $(180 \mathrm{~m} \times$ $65 \mathrm{~m}$ ), thinned to differing tree densities. The plots were located next to each other on a homogeneous area of 8.2 ha. Treatments were allocated randomly to the plots. The control plot was left undisturbed (referred to as the $100 \%$ plot), and the others thinned to the approximate equivalents of $75 \%, 50 \%, 35 \%, 20 \%, 10 \%$ and $0 \%$ (total clearing) of the tree biomass of that of the $100 \%$ plot. The control plot was characterized by a dense stand of C. mopane with herbaceous plants almost completely absent.

The occurrence of dwarf growth forms of C. mopane is known to exist. In the Kruger National Park, all C. mopane growing on soils derived from basic material i.e. basalt, diabase/dolorite and gabbro are multi-stemmed shrubs with a mean height of 1-2 m, while C. mopane growing on sandy soils are usually single-stemmed and up to $5 \mathrm{~m}$ tall [48]. The C. mopane trees of the study area at the onset of the study had a mean height of $2.47 \mathrm{~m}(\mathrm{SE} \pm 0.052)$, with a mean canopy diameter of $1.68 \mathrm{~m}(\mathrm{SE} \pm 0.064)$. A large percentage of them was multi-stemmed. No specific information on the ages of the trees is available, but according to local inhabitants this specific dense stand of $C$. mopane trees was in existence for a number of years, though some older members can remember a time when the area was sparsely covered with trees.

Trees were randomly marked for removal during the thinning process. This ensured a fairly even spread of the remaining trees without favouring a particular tree size. 
The resultant thinned plots resembled the structure of naturally occurring open stands of C. mopane. During thinning, trees were sawn off at ground level and removed from the plot. The stumps were sprayed with a $1 \%$ concentration of picloram and triclopyr (Tordon Super) mixed in diesel, thus ensuring that the sawn trees were killed without affecting the remaining plants. The study area was fenced to exclude grazing or browsing animals. The tree thinning was completed during the winter of 1989 and the tree densities (trees ha-1) were as follows: $100 \%$ (control) plot $-2711 ; 75 \%$ plot $-1978 ; 50 \%$ plot $-1233 ; 35 \%$ plot $-744 ; 20 \%$ plot $-589 ; 10 \%$ plot -300 and $0 \%-0$ trees $\mathrm{ha}^{-1}$. The response of the herbaceous layer was studied during the three growing seasons following tree thinning.

\section{Rainfall}

Daily rainfall data were recorded as the mean of four standard rain gauges (127 $\mathrm{mm}$ diameter), placed at each of the four corners of the experimental area (Figure 3).

\section{Quantification of the woody layer}

The purpose of the survey of the woody layer was primarily aimed at obtaining some quantitative data of the leaf biomass of the remaining C. mopane trees for purposes of establishing the relationship between the above ground woody and herbaceous biomass.

At the end of each growing season, normally April or May, the canopy of all rooted live C. mopane trees encountered in fixed transects $(5 \mathrm{~m} \times 180 \mathrm{~m})$ located in the middle of each of the experimental plots, was measured. The measurements consisted of the following $[49,50]$ : (i) maximum tree height, (ii) height where the maximum canopy diameter occurs, (iii) height of first leaves or potential leaf bearing stems, (iv) maximum canopy diameter, and (v) base diameter of the foliage at the height of the first leaves. The canopy volume of the trees, regardless of their shape or size, was calculated from these dimension measurements by using the volume formulas of an ellipsoid, a right circular cone, a frustum of right circular cone or a right circular cylinder. Depending on the shape of the tree, any one of these volume formulas may be used, or more likely two of them in combination. A comprehensive description of the procedure is given by Smit [50].

Leaf volume estimates $\left(\mathrm{cm}^{3}\right)$ were calculated using the BECVOL-model (Biomass Estimates from Canopy Volume) $[26,51]$, which is based on the quantitative description technique proposed by Smit $[49,50]$. It includes regression equations, developed from harvested trees, which relate the spatial canopy volume (independent variable) to the actual leaf volume (dependant variable): $\ln \mathrm{y}$ $=-4.34074+0.7601 \mathrm{x}, \mathrm{r}=0.963, \mathrm{P}<0.001$. Spatial tree canopy volume (x) is transformed to its normal logarith- mic value, while y represents the estimated leaf volume $\left(\mathrm{cm}^{3}\right)$. The number of Evapotranspiration Tree Equivalents (ETTE) $\mathrm{ha}^{-1}$ was subsequently calculated from the leaf volume estimates $(1 \mathrm{ETTE}=$ mean leaf volume of a 1.5 $\mathrm{m}$ tall single-stemmed tree $=500 \mathrm{~cm}^{3}$ leaf volume) [49]. Since the ETTE-values is based on estimates of actual leaf biomass it is considered a more accurate measure of potential competition of woody plants compared to simple density data (plants ha-1).

\section{Quantification of the herbaceous layer}

Three subhabitats were distinguished: between tree canopies (uncanopied - UCA), under tree canopies (canopied - CA) and where trees have been removed (removed canopy - RCA). The C. mopane trees do not have wide spreading canopies. Closed canopies [15] are thus largely absent. The various subhabitats were consequently not considered to be purely a function of the area overspanned by the tree canopies, but also of the soil. Large scale loss of topsoil, partially retained under the trees, has led to distinctive elevated soil surface patterns. The CA and RCA subhabitats are subsequently often smaller in diameter than the immediate overstory canopy spread. Due to the relatively close proximity of the trees, as well as an extensive horizontal spread of the roots of $C$. mopane [17], the uncanopied subhabitat fell within the root zone of the trees, even at the lowest tree density.

Areas covered by the various subhabitats were determined for each of the experimental plots. Subhabitat areas, which were mostly circular in shape, were determined from two diameter measurements rectangular to each other. The area of either a fitting circle or ellipsoid was calculated [52]. Only the areas of the CA and RCA subhabitats were measured. For each experimental plot the area of the UCA subhabitat was calculated from subtracting the combined areas of the two measured subhabitats from the total area of each experimental plot (1.17 ha).

Above-ground dry matter (DM) yield of herbaceous plants within the seven tree density plots was determined at the end of each growing season, normally April or May. A harvest technique $[53,54]$ was employed, which provided estimates of net primary production $[55,56]$ less possible dry matter loss due to grass mortality. Losses due to grazing during the growing season were prevented by the fencing of the study area. Controlled grazing by cattle during the dormant season annually, ensured that carryover from one season to another was low.

Grasses (species basis) and forbs (non-species basis) were harvested in quadrates $\left(0.25 \mathrm{~m}^{2}\right)$, randomly placed in each of the subhabitats. A total of 60 quadrates per experimental plot were harvested, 20 randomly allocated per subhabitat. In those plots where only 2 of the 3 defined 
subhabitats were represented ( $0 \%$ and $100 \%$ plots), 30 quadrates were harvested on each of the 2 represented subhabitats. Rooted herbaceous plants within each quadrate were clipped to stubble height using hand clippers. Stubble height varied from $0.1-3.0 \mathrm{~cm}$, depending whether the species was tufted or not. The clipped material was dried to a constant mass $\left(70^{\circ} \mathrm{C}\right)$ and weighed.

\section{Data analyses}

In testing for treatment effects, care was taken to avoid the use of pseudo-replications [57]. Relations between tree leaf biomass (dry basis) and the DM yield of herbaceous plants (grasses and forbs) were established using regression analyses [58,59]. For the determination of differences in trend of grass DM yield between habitats and subhabitats, the total grass DM yield within the various habitats and subhabitats of the experimental plots after each successive season ( $\mathrm{x}$-axis), was subjected to the fitting of polynomials. Polynomials (linear, quadratic or cubic) with the best fit were selected and paired combinations of these selected polynomials were subsequently tested for contrasts on the $\mathrm{x}$-axis (tree density) using the procedures of Groeneveld [29].

\section{List of abbreviations}

BECVOL - Biomass Estimates from Canopy Volume

CA - Canopied (under tree canopies)

DM - Dry mass

ETTE - Evapotranspiration Tree Equivalents $(1$ ETTE = mean leaf volume of a $1.5 \mathrm{~m}$ single-stemmed tree $=500$ $\mathrm{cm}^{3}$ leaf volume)

RCA - Removed Canopy (where trees were removed)

UCA - Uncanopied (between tree canopies)

\section{Authors' contributions}

All aspects of the study were conducted by the author with assistance as indicated under Acknowledgements.

\section{Acknowledgements}

The field assistance of A. le Roux and the late J.S. Swart is gratefully acknowledged. Mrs M.F. Smith is thanked for her help with the statistical analysis.

\section{References}

I. O'Connor TG, Crow VRT: Rate and pattern of bush enchroachment in Eastern Cape savanna and grassland. African Journal of Range and Forage Science 1999, 16:26-31.

2. Teague WR, Smit GN: Relations between woody and herbaceous components and the effect of bush-clearing in southern African savannas. Journal of the Grassland Society of Southern Africa 1992, 9:60-7I.

3. Roques KG, O'Connor TG, Watkinson AR: Dynamics of shrub encroachment in an African savanna: relative influence of fire, herbivory, rainfall and density dependence. Journal of Applied Ecology 200I, 38:268-280.

4. Ringrose S, Chipanshi AC, Chanda AC, Matheson R, Motoma L, Magole I, Jellema A: Climate - and human-induced woody vegetation changes in Botswana and their implications for human adaptation. Environmental Management 2002, 30:98-109.

5. Smit GN: An approach to tree thinning to structure southern African savannas for long-term restoration from bush encroachment. Journal of Environmental Management 2004, 71:103-109.

6. Smit GN, Rethman NFG, Moore A: Review article: Vegetative growth, reproduction, browse production and response to tree clearing of woody plants in African savanna. African Journal of Range and Forage Science 1996, 2:78-88.

7. Donaldson $\mathrm{CH}$, Kelk DM: An investigation of the veld problems of the Molopo area: I. Early findings. Proceedings of the Grassland Society of southern Africa 1970, 5:50-57.

8. Dye PJ, Spear PT: The effects of bush clearing and rainfall variability on grass yield and composistion in south-west Zimbabwe. Zimbabwe Journal of Agricultural Research 1982, 20:103-118.

9. Richter CGF, Snyman HA, Smit GN: The influence of tree density on the grass layer of three semi-arid savanna types of southern Africa. African Journal of Range and Forage Science 2001, I 8: I-7.

10. Scholes RJ: Response of three semi-arid savannas on contrasting soils to the removal of the woody component. Ph.D-thesis, University of the Witwatersrand, Johannesburg 1987.

II. Smit GN, Rethman NFG: The influence of tree thinning on the establishment of herbaceous plants in a semi-arid savanna of southern Africa. African Journal of Range and Forage Science 1999, 16:9-18.

12. Belsky AJ, Amundson RG, Duxbury JM: The effects of trees on their physical, chemical and biological environments in a semi-arid savanna in Kenya. Journal of Applied Ecology 1989, 26:1005-1024.

13. Kellman M: Soil enrichment by neotropical savanna trees. Journal of Ecology 1979, 67:565-577.

14. Smit GN, Swart JS: The influence of leguminous and non-leguminous woody plants on the herbaceous layer and soil under varying competition regimes in Mixed Bushveld. African Journal of Range and Forage Science 1994, I I:27-33.

15. Kennard DG, Walker BH: Relationship between tree canopy cover and Panicum maximum in the vicinity of Fort Victoria. Rhodesia Journal of Agricultural Research 1973, I I: | 45- I 53.

16. Mapaure I: The distribution of mopane. Kirkia 1994, I5: 1-5.

17. Smit GN, Rethman NFG: Root biomass, depth distribution and relations with leaf biomass of Colophospermum mopane. South African Journal of Botany 1998, 64:38-43.

18. Smit GN, Rethman NFG: The influence of tree thinning on the soil water in a semi-arid savanna of southern Africa. Journal of Arid Environments 2000, 44:4l-59.

19. Acocks JPH: Veld types of South Africa. In Memoirs of the Botanical Survey of South Africa Volume 57. 3rd edition. Government Printer (1953); 1988

20. Low AG, Rebelo AG: Vegetation of southern Africa, Lesotho and Swaziland. Ist edition. Department of Environmental Affairs \& Tourism: Pretoria; 1996:83.

21. Louw AJ: An ecological study of the Mopane veld north of the Soutpansberg. D.Sc-thesis, University of Pretoria, Pretoria, South Africa 1970.

22. Agassi M, Shainberg I, Morin J: Effect of electrolyte concentration and soil sodicity on infiltration rate and crust formation. Soil Science Society of America Journal I 981, 45:848-85I.

23. Harmse $H$ J, von $M, N$ el DJ: Chemical amelioration of a Swartland soil with prominent crusting. Applied Plant Science 1990, 4:62-66.

24. Hillel D, Gardner WR: Transient infiltration into crust-topped profiles. Soil Science 1970, 109:69-76.

25. Ralph W: Water-ponding reclaims inland soils. Rural Research 1989, 144:9-12.

26. Smit GN: The influence of intensity of tree thinning on Mopani veld. Ph.D-thesis, University of Pretoria, Pretoria 1994.

27. Smit GN: The influence of tree thinning on the vegetative growth and browse production of Colophospermum mopane. South African Journal of Wildlife Research 200 I, 3 I:99-I I4. 
28. Smit GN, Rethman NFG: The influence of tree thinning on the reproductive dynamics of Colophospermum mopane. South African Journal of Botany 1998, 64:25-29.

29. Groeneveld HT: Method for testing contrasts among polynomials. Agrochemophysica 1970, 2:47-52.

30. Wilson JB: Shoot competition and root competition. Journal of Applied Ecology 1988, 25:279-296.

31. Wu H, Sharp PJH, Walker J, Penridge LK: Ecological field theory: a spatial analysis of resource interference among plants. Ecological Modelling 1985, 29:215-243.

32. Harrington GN, Johns GG: Herbaceous biomass in a Eucalyptus savanna wood land after removing trees and/or shrubs. Journal of Applied Ecology 1990, 27:775-787.

33. Scanlan JC, Burrows WH: Woody overstory impact on herbaceous understory in Eucalyptus spp. communities in central Queensland. Australian Journal of Ecology 1990, I5:191-197.

34. Walker BH, Stone L, Henderson L, Vernede M: Size structure analysis of the dominant trees in a South African savanna. South African Journal of Botany 1986, 52:397-402.

35. Winter WH, Mott J, McLean RW: Evaluation of management options for increasing the productivity of tropical savanna pastures 3. Trees. Australian Journal of Experimental Agriculture 1989, 29:63I-634.

36. Archer S, Scifes C, Bassham CR: Autogenic succession in a subtropical savanna: conversion of grassland to thorn woodland. Ecological Monographs 1988, 58: I I I-I 27.

37. Bozzo JA, Beasom SL, Fulbright TE: Vegetation responses to 2 brush management practices in south Texas. Journal of Range Management 1992, 45:170-175.

38. Haworth K, McPherson GR: Effexts of Quercus emoryi on herbaceous vegetation in a semi-arid savanna. Vegetatio 1994, I 12:153-159.

39. Scifres CJ: Economic assessment of tebuthiuron-fire systems for brush management. Weed Technology 1987, I:22-28.

40. Scifres CJ, Mutz JL, Whitson RE, Drawe DL: Interrelationships of huisache canopy cover with range forage on the coastal prairie. Journal of Range Mangement 1982, 35:558-562.

4I. Smit GN, Rethman NFG: Implications of subhabitat diversity and the role of management on the occurrence of a number of grass species of the Sourish-Mixed Bushveld. Journal of the Grassland Society of southern Africa 1989, 6:44-50.

42. Stuart-Hill GC, Tainton NN, Barnard HJ: The influence of an Acacia karroo tree on grass production in its vicinity. Journal of the Grassland Society of southern Africa 1987, 4:83-88.

43. Tiedemann AR, Klemmedson JO: Effect of Mesquite on physical and chemical properties of the soil. Journal of Range Management 1973, 26:27-29.

44. Yavitt JB, Smith EL: Spatial patterns of mesquite and associated herbaceous species in an Arizona desert grassland. American Midland Naturalist 1983, 109:89-93.

45. Ellis JE, Swift DM: Stability of African pastoral ecosystems: alternative paradigms and implications for development. Journal of Range Management 1988, 41:458-459.

46. Higgins SI, Bond WJ, Trollope WSW: Fire, reprouting and variability: a recipe for grass-tree coexistence in savanna. Journal of Ecology 2000, 88:213-229.

47. Illius $\mathrm{AW}, \mathrm{O}^{\prime}$ Connor TG: On the relevance of non-equilibrium concepts to arid and semi-arid grazing systems. Ecological Applications 1999, 9:798-8I3.

48. Fraser SW, Van Rooyen TH, Verster E: Soil-plant relationships in the central Kruger National Park. Koedoe 1987, 30:19-34.

49. Smit GN: Quantitative description of woody plant communities: Part I. An approach. Journal of the Grassland Society of southern Africa 1989, 6:186-191.

50. Smit GN: Quantitative description of woody plant communities: Part II. Computerized calculation procedures. Journal of the Grassland Society of southern Africa 1989, 6:192-194.

5I. Smit GN: BECVOL: Biomass Estimates from Canopy VOLume (version 2) - Users Guide. Unpublished manual, University of the Free State, Bloemfontein 1996:22.

52. Spiegel MR: Mathematical handbook. Schaum's outline series. McGraw-Hill book series 1968.

53. Catchpole WR, Wheeler CJ: Estimating plant biomass: a review of techniques. Australian Journal of Ecology 1992, I7:|21-131.
54. Grunow JO, Groenewald HT, Du Toit SHC: Above-ground dry matter dynamics of the grass layer of a South African tree savanna. Journal of Ecology 1980, 68:877-889.

55. Deshmukh IK, Baig MN: The significance of grass mortality in the estimation of primary production in African grasslands. African Journal of Ecology 1983, 2 I: 19-23.

56. Grossman D: Primary production of rangeland: practical and interpretive problems. Proceedings of the Grassland Society of southern Africa 1982, I 7:76-78.

57. Hurlbert SH: Pseudoreplication and the desigh of ecological field experiments. Ecological Monographs 1984, 54:187-2II.

58. Draper N, Smith $\mathrm{H}$ : Applied regression analysis. Wiley \& Sons, New York; 198I.

59. Statgraphics: STSC Inc. USA 1991.
Publish with Biomed Central and every scientist can read your work free of charge

"BioMed Central will be the most significant development for disseminating the results of biomedical research in our lifetime. "

Sir Paul Nurse, Cancer Research UK

Your research papers will be:

- available free of charge to the entire biomedical community

- peer reviewed and published immediately upon acceptance

- cited in PubMed and archived on PubMed Central

- yours - you keep the copyright

Submit your manuscript here:

http://www.biomedcentral.com/info/publishing_adv.asp
BiolMedcentral 